\title{
Peningkatan Prestasi Belajar Mahasiswa Semester VII pada Mata Kuliah Teknologi Fermentasi melalui Implementasi Metode Eksperimen
}

\author{
Indro Prastowo, Muh. Joko Susilo, Novi Febrianti, Nani A., Hani Irawati, Yahya H. \\ Progam Studi Pendidikan Biologi, Universitas Ahmad Dahlan \\ Kampus III, Jl. Prof. Dr. Soepomo, SH, Yogyakarta, 55164 Indonesia \\ surat elektronik: indro.prastowo25@,gmail.com
}

\begin{abstract}
ABSTRAK
Mata kuliah Teknologi Fermentasi merupakan salah satu mata kuliah pilihan pada Program Studi Pendidikan biologi Universitas Ahmad Dahlan yang bertujuan untuk memberikan ketrampilan kepada mahasiswa agar mampu memanfaatkan mikrobia untuk menghasilkan berbagai produk fermentasi. Selama ini pembelajaran pada mata kuliah Teknologi Fermentasi dilakukan dengan metode ceramah Penggunaan metode ceramah membuat mahasiswa pasif dan hasil belajarnya rendah. Untuk meningkatkan hasil belajar mahasiswa dilakukanlah kegiatan Lesson Study.

Aktivitas Lesson Study dibagi menjadi 3 aktivitas utama yaitu : plan, do, dan see, semua aktivitas dilakukan secara berkolaborasi antar dosen di program studi pendidikan biologi. Implementasi kegiatan Lesson Study (LS) melibatkan I orang dosen model dan 8 dosen sebagai observer serta 62 mahasiswa semester 7. Pada kegiatan pembelajaran mata kuliah Teknologi Fermentasi digunakan berbagai macam metode pembelajaranya yaitu: diskusi, presentasi, dan eksperimen dengan tujuan untuk meningkatkan hasil belajar mahasiswa.

Kegiatan Lesson Study dilaksanakan selama empat siklus. Hasil penelitian menunjukkan bahwa dengan Implementasi Lesson Study hasil belajar mahasiswa pada mata kuliah Teknologi Fermentasi secara keseluruhan meningkat. Agar Lesson Study dapat berjalan dengan lancar perlu komitmen yang kuat dari seluruh dosen yang terlibat dalam kegiatan Lesson Study baik dosen model maupun para observer.
\end{abstract}

Kata kunci: Lesson Study, hasil belajar, mata kuliah Teknologi Fermentasi

\section{Pendahuluan}

Kegiatan pembelajaran merupakan interaksi antara pendidik dan peserta didik untuk mencapai tujuan pembelajaran dan menanamkan sikap dan nilai pada diri peserta didik. Proses pembelajaran tidak hanya bertujuan untuk menyampaikan materi perkuliahan dari dosen kepada mahasiswa saja, akan tetapi juga untuk menanamkan karakter positif dalam diri mahasiswa.

Mata kuliah Teknologi Fermentasi merupakan salah satu mata kuliah pilihan pada program studi pendidikan biologi Universitas Ahmad Dahlan. Mata kuliah ini bertujuan untuk memberikan ketrampilan kepada mahasiswa agar mampu memanfaatkan mikrobia untuk menghasilkan berbagai produk fermentasi. Selama ini pembelajaran pada mata kuliah Teknologi Fermentasi dilakukan dengan metode ceramah. Metode ini ternyata belum mampu untuk membangkitkan jiwa kerja sama antar-mahasiswa karena tidak terjadinya interaksi antar dosen dan mahasiswa dan antar-mahasiswa dengan mahasiswa.

Berdasarkan observasi pendahuluan mahasiswa lebih banyak yang pasif pada saat pembelajaran dan hanya sebagian kecil yang aktif. Kurangnya kerjasama antarmahasiswa menyebabkan tidak adanya transfer pengetahuan dari mahasiwa yang memilki kemampuan lebih kepada mahasiswa yang memiliki kemampuan rendah, sehingga rata-rata hasil belajarnya rendah. Ratarata nilai mahasiswa sebesar 65,8 sehingga perlu adanya perubahan metode pembelajaran agar kerja sama dan hasil belajar mahasiswa lebih tinggi.

Metode pembelajaran yang dipilih adalah metode ekperimen. Menurut Roestiyah (200I: 80) metode eksperimen adalah suatu cara mengajar dimana peserta didik melakukan suatu percobaan tentang sesuatu hal, mengamati prosesnya serta menuliskan hasil percobaannya, kemudian hasil pengamatan itu disampaikan di depan kelas dan dievaluasi oleh pendidik. Penggunaan metode eksperimen pada 
perkuliahan Teknologi Fermentasi dilakukan secara berkelompok dengan tujuan untuk membangkitkan jiwa kerjasama antar-mahasiswa dan terjadinya transfer pengetahuan antar-mahasiswa.

\section{Metode Penelitian}

Aktivitas Lesson Studi pada dasarnya dibagi 3 aktivitas utama yaitu: plan, do, dan see. Beberapa penelitian menyebutkan bahwa kegiatan ini melibatkan guru atau dosen dalam pembelajaran di dalam kelas. Implementasi kegiatan Lesson Study (LS) yang dilakukan di kelas ini melibatkan I orang dosen model dan dosen lain sebagai observer (Nahdi, 2007).

Pada kegiatan ini, Lesson Study yang ditujukan untuk meningkatkan kerjasama dan hasil belajar mahasiswa dilakukan pada mata kuliah Teknologi Fermentasi tahun ajaran 2014/2015 yang terdiri 62 mahasiswa semester 7. Satu orang dosen ditunjuk sebagai dosen model, sementara itu dosen lainnya berperan sebagai observer ( 8 dosen) dan kameraman (I dosen). Implementasi Lesson Study dilakukan pada tanggal 29 September 2014 hingga 5 November 2014 yang dilakukan selama 4 siklus.

Pada tahap plan, seluruh dosen yang terlibat dalam kegiatan ini mengidentiifikasi permasalahan selama proses pembelajaran. Perencanaan pembelajaran, Lembar Kerja Mahasiswa (LKM) dan Lembar Observasi (LO) dibuat pada tahap ini. Lembar observasi (LO) digunakan untuk mengumpulkan data berkaitan dengan aktivitas siswa selama pembelajaran.

Tahap selanjutnya adalah do, yang berarti implementasi Lesson Study di kelas. Pada kegiatan ini, dosen model melakukan proses pembelajaran di dalam kelas sementara itu observer melakukan observasi proses pembelajaran selama pembelajaran. Pada lain kesempatan, dokumentator melakukan dokumentasi proses pembelajaran.

Tahap terakhir, see atau refleksi, seluruh observer, dosen model dan kameraman/fotografer berkumpul di suatu ruangan untuk membahas pembelajaran yang telah dilakukan dikelas. Dosen model diberikan kesempatan pertama untuk mengungkapkan kesan-kesannya terhadap proses pembelajaran di kelas. Kemudian, observer memberikan opini dan serta temuan-temuan selama proses pembelajaran, didukung oleh video yang didapat selam proses pembelajaran.

Pada artikel ini, data hasil pembelajaran diperoleh dari post test dari setiap siklus. Tes ini dilakukan pada akhir perkuliahan. Kriteria Ketuntasan Minimal (KKM) untuk mata kuliah ini adalah 70. Dasar dari penentuan KKM ini didasarkan pada rerata nilai tahun lalu. Di lain pihak, Lembar Observasi (LO) diisi oleh observer pada saat mengamati proses pembelajaran.

\section{Hasil dan Pembahasan}

Nilai mahasiswa selama 4 siklus dapat dilihat pada gambar I. Pada siklus pertama rerata nilai adalah 52,54. Pada siklus kedua, nilai rerata mahasiswa naik menjadi 69,91. Pada siklus ketiga dan keempat, nilai rerata mahasiswa naik menjadi 88,54 dan 90,18. Rerata nilai mahasiswa siklus I $(52,54)$ masih dibawah KKM, yaitu 70. Apabila dilihat dari presentase ketidaktuntasan KKM, pada siklus I mencapai 89,09 \% (Gambar 2). Kemudian pada siklus 2, presentase ketidaktuntasan KKM menurun menjadi I2,72 \% (Gambar 2). Sedangkan pada siklus 3 dan siklus 4, presentase ketidaktuntasan KKM adalah 0 \%.

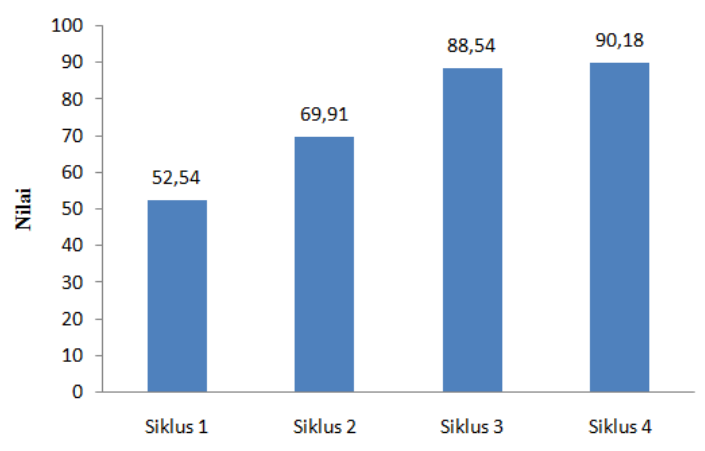

Gambar I. Rerata Nilai Mahasiswa

Pada siklus I, nilai mahasiswa rendah dan presentase ketidaktuntasan KKM begitu tinggi karena pada tahap ini mahasiswa sedang menyesuaikan dengan model pembelajaran inkuiri. Pada siklus I ini, mahasiswa diberi tugas untuk mengamati ciri-ciri inokulum yang baik dan diminta mendesign pengembangan inokulum sebelum proses fermentasi.

Pada siklus kedua, rerata nilai mahasiswa naik menjadi 69,9I dan presentase ketidaktuntasan KKM turun drastis menjadi $12,72 \%$. Hal ini disebabkan karena mahasiswa sudah beradaptasi terhadap model pembelajaran inkuiri dimana mahasiswa belajar dari apa yang mereka amati. Pada siklus 2 ini, mahasiswa belajar mengenai penyusunan medium fermentasi. Mahasiswa ditugaskan untuk mencari informasi melalui 2 cara yaitu, melaui kegiatan eksperimen dan melaui video. Peningkatan rerata nilai mahasiswa tidak terlalu drastis karena pada beberapa anak yang mengamati video mengalami kebosanan sehingga ini berpengaruh pada naiknya rerata nilai mahasiswa yang tidak terlalu tinggi.

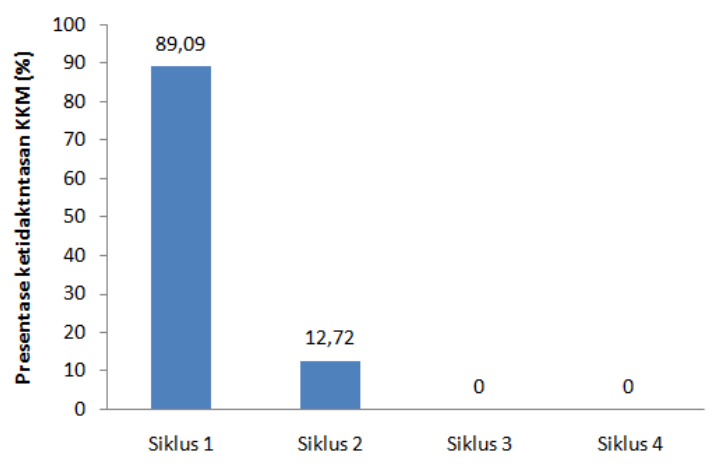

Gambar 2. Presentase ketidaktuntasan KKM 
Pada siklus ketiga, nilai rerata mahasiswa naik menjadi 88,09 dan presentase ketidaktuntasan KKM turun menjadi $0 \%$. Hal ini disebabkan mahasiswa sudah sangat beradaptasi dan menikmati model pembelajaran inkuiri. Pada tahap ini, mahasiswa belajar mengenai faktor-faktor yang mempengaruhi fermentasi. Mahasiswa disini ditugaskan untuk mengamati proses fermentasi yang dipengaruhi beberapa faktor: $\mathrm{pH}$, suhu, kontaminasi dan pengadukan.

Pada siklus keempat, rerata nilai mahasiswa naik sedikit menjadi 90,18 sementara itu presentase ketidaktuntasan KKM tetap $0 \%$. Pada tahap ini, mahasiswa mengamati proses pengunduhan hasil fermentasi melaui video. Pada tahap ini, mahasiswa sudah sangat menikmati suasana pembelajaran sehingga rerata nilai mahasiswa tinggi dan presentase ketidaktuntasan KKM 0\%.

\section{Simpulan}

Dengan implementasi Lesson Study, hasil belajar mahasiswa pada mata kuliah Teknologi Fermentasi secara keseluruhan meningkat. Agar Lesson study dapat berjalan dengan lancar perlu komitmen yang kuat untuk seluruh dosen yang terlibat, baik dosen model maupun dosen yang menjadi observer.

\section{Daftar Pustaka}

Daniel Muijs dan David Reynolds. 2008. Efefective

Teaching-Teori dan Aplikasi. Yogyakarta: Pustaka Pelajar.

Oemar Hamalik. 2002. Pendidikan Guru Berdasarkan Pendekatan Kompetensi. Jakarta: Bumi Aksara. . 2004. Psikologi Belajar Mengajar. Bandung: Sinar Baru Algensindo.

Richard L.Arends. 2008. Learning To Teach-Belajar untuk Mengajar. Yogyakarta: Pustaka Pelajar. 